\title{
MECHANICAL PROPERTIES, WATER ABSORPTION, AND FAILURE ANALYSES OF KENAF FIBER REINFORCED EPOXY MATRIX COMPOSITES
}

\author{
IKHWAN YUSUFF, NORSHAHIDA SARIFUDDIN* \\ Siti NORBAHIYAH AND AFIFAH MOHD ALI \\ Department of Manufacturing and Materials Engineering, \\ Kulliyyah of Engineering, International Islamic University Malaysia, \\ Jalan Gombak, 53100 Kuala Lumpur, Malaysia \\ *Corresponding author: norshahida@iium.edu.my
}

(Received: $16^{\text {th }}$ December 2020; Accepted: $22^{\text {nd }}$ February 2021; Published on-line: $4^{\text {th }}$ July 2021)

\begin{abstract}
The potential of natural fibers as one of the candidate materials in the production of fiber-reinforced polymer composites have been widely investigated. In the current study, natural fiber-reinforced polymer composite was fabricated by employing woven kenaf fiber as a reinforcing agent with epoxy resin that acts as a matrix constituent. This composite sample was fabricated using the application of the vacuum infusion method in which the content of kenaf fibers was varied from $30 \mathrm{vol} . \%, 40$ vol.\%, and $50 \mathrm{vol} . \%$. The effects of different fiber loadings toward mechanical and physical properties as well as failure properties of kenaf composite were then evaluated. Kenaf composites were subjected to mechanical tests including tensile and flexural tests. The result shows that the highest tensile strength and modulus were attained at 76.67 $\mathrm{MPa}$ and $2.31 \mathrm{GPa}$, respectively with kenaf composite fabricated with $40 \mathrm{vol}$.\% fiber content. Meanwhile, the highest flexural strength and modulus were recorded at 61.24 $\mathrm{MPa}$ and $4.20 \mathrm{GPa}$, also corresponding to kenaf composite that is loaded with $40 \mathrm{vol} . \%$ fibers. Fiber pull-out failure was able to be detected in fabricated kenaf composites. Meanwhile, fiber breakage resulting from flexural failure could also be observed in the kenaf composite samples. Apart from that, it was found that as more kenaf fiber was loaded in the composites, the rate of water absorption tended to increase where the highest rate of water absorption was found at $43.33 \%$, displayed by kenaf composite with 50 vol.\% of fiber content.
\end{abstract}

ABSTRAK: Potensi gentian semula jadi sebagai salah satu bahan dalam penghasilan komposit polimer bertetulang gentian telah banyak dikaji. Dalam kajian terkini, komposit polimer yang diperkuat dengan gentian semula jadi dibuat dengan menggunakan serat kenaf tenunan sebagai agen penguat dan resin epoksi yang bertindak sebagai matriks. Sampel komposit ini dibuat menggunakan kaedah infusi vakum di mana kandungan serat kenaf digunakan adalah 30 vol.\%, 40 vol.\%, dan 50 vol.\%. Kesan kandungan serat yang berbeza terhadap sifat mekanikal dan fizikal serta sifat kegagalan komposit kenaf kemudiannya dinilai. Komposit Kenaf diuji dengan ujian tegangan dan lenturan. Hasilnya menunjukkan bahawa kekuatan tegangan dan modulus tertinggi dicapai pada 76.67 $\mathrm{MPa}$ dan 2.31 GPa, milik komposit kenaf yang dibuat dengan kandungan serat 40 vol.\%. Sementara itu, kekuatan dan modulus lenturan tertinggi dicatatkan pada $61.24 \mathrm{MPa}$ dan 4.20 GPa juga milik komposit kenaf yang dimuatkan dengan serat $40 \%$ vol. Kegagalan serat terkeluar dapat dikesan pada komposit kenaf buatan. Sementara itu, kerosakan serat akibat kegagalan lenturan juga dapat dilihat pada sampel komposit kenaf. Selain itu, didapati bahawa semakin banyak serat kenaf yang dimuatkan dalam komposit, cendurung meningkatkan kadar penyerapan air di mana 
kadar penyerapan air tertinggi didapati pada $43.33 \%$ yang ditunjukkan oleh komposit kenaf dengan kandungan serat $50 \%$ vol.

KEYWORDS: natural fiber; kenaf composite; mechanical properties

\section{INTRODUCTION}

The exploitation of natural fibers such as kenaf, hemp, sisal, and bamboo has been widely adopted in the production of fiber-reinforced composite materials [1,2]. The growth of natural-based composites is due to the properties of natural fibers, especially in terms of cost and biodegradability characteristics [3,4]. Moreover, the excellent biodegradability displayed by natural fibers can impart a positive impact on the environment due to the ability to form green bio-composite materials. Furthermore, the capability of natural fibers in offering outstanding attributes including non-abrasiveness, low density, as well as exhibiting a comparable specific strength, is another driving force in the utilization of this fiber as a reinforcement in fiber-reinforced composite materials $[5,6]$.

Therefore, there are many works available in open literature that have reported on the potential of natural fiber utilization in many engineering applications such as construction, electronic, and automotive industries [7,8]. For example, Javadian et al. [9] have investigated the mechanical properties of bamboo fiber to be embedded in composites for construction uses. Moreover, Gupta [10] has studied the potential of jute composites for electronic applications. The author has found that jute composite shows acceptable dynamic mechanical properties that are suitable for application in making the casing for electronic devices such as mobile phones and laptops. Recently, Yang et al. [11] have reviewed the future of cellulosic fiber-based (kenaf, bamboo, banana, and pineapple leaf) composites for marine applications. The authors have mentioned that cellulosic fibers (natural fibers) gain great attention in marine applications due to the drawbacks of synthetic fibers, including high cost, poor recyclability, and high embodied energy.

Moreover, synthetic-based composites are often disposed of in improper ways. Incineration after end-of-service may cause serious air pollution and this is another reason that prompted the idea of developing natural fiber-based composites [12]. It is believed that the introduction of natural fibers in composite industries has created a new option, especially for the manufacturers in developing cost-effective green products with comparable mechanical properties. Recently, the potential of kenaf fibers to be used as door panels in automotive parts has been discovered [13]. Thus, it is necessary to have continuous research that explores the potentials, limitations, and barriers in growing natural fiber composites so that the properties and behaviors of this composite can be properly verified. Therefore, the current research is one of the approaches taken to ensure continuity in the development of natural fiber-based composites in order to discover the abilities of these natural resources for future use.

\section{MATERIALS AND EXPERIMENTAL DESIGNS}

\subsection{Materials}

Plain woven kenaf fiber with an average thickness of $0.8 \times 10^{-3} \mathrm{~m}$ and density of 1220 $\mathrm{kg} / \mathrm{m}^{3}$ was utilized as a reinforcing element. Meanwhile, epoxy resin grade INF -114 with corresponding hardener INF - 212 and density of $1140 \mathrm{~kg} / \mathrm{m}^{3}$ was applied as a matrix 
constituent to bind the fibers where the ratio of epoxy-to-hardener was fixed at 100:24.7 (

\subsection{Preparation of Kenaf Reinforced Epoxy Matrix Composites}

Kenaf composites were fabricated based on three different fiber loadings including 30 vol. $\%, 40 \mathrm{vol} . \%$, and $50 \mathrm{vol} . \%$. Woven kenaf fibers were cut into dimensions of $300 \mathrm{~mm} \times$ $150 \mathrm{~mm}$ and $150 \mathrm{~mm} \times 150 \mathrm{~mm}$ for tensile test and flexural test, respectively. Meanwhile, pristine epoxy was also fabricated as a control sample. The fabrication process involves the application of vacuum infusion method in which epoxy resins were infused within the layer of kenaf fibers using constant pressure at $-100 \mathrm{kPa}$ supplied from a vacuum pump. The curing process at room temperature was performed for 24 hours once the epoxy resin completely covered the plies of kenaf fibers in order to solidify the composite panels. Fig. 1 illustrates the schematic diagram of experimental set up for fabrication of kenaf composite panels via vacuum infusion method.

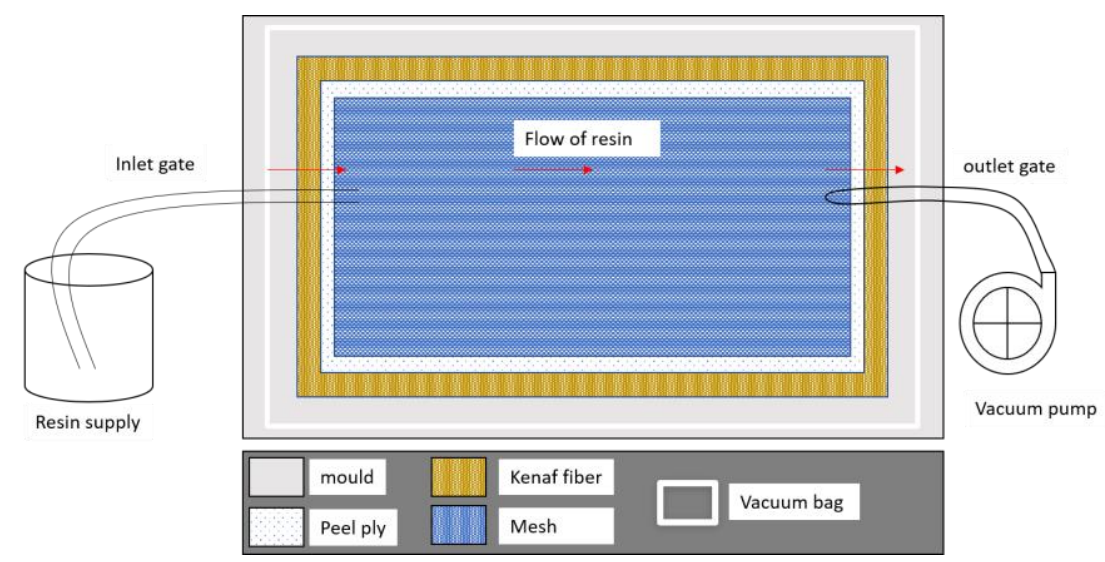

Fig. 1: Schematic diagram of the vacuum infusion layout in the fabrication of kenaf composite panel.

\subsection{Characterization of Kenaf Composite Panels}

Kenaf composites were subjected to three main characterizations including mechanical, physical, and morphological analyses. The mechanical properties were characterized under tensile and flexural tests. For tensile test, samples were cut into dimension of $250 \mathrm{~mm} \times 25 \mathrm{~mm}$ in accordance with ASTM D3039. This testing was performed using a Universal Testing Machine (UTM) Instron 5582 with a load of $100 \mathrm{kN}$ and crosshead speed of $2 \mathrm{~mm} / \mathrm{min}$. Meanwhile, for the flexural test, the same machine was used where samples were prepared with a dimension of $127 \mathrm{~mm} \times 13 \mathrm{~mm}$ corresponding to ASTM D970. The same load of $100 \mathrm{kN}$ and crosshead speed $2 \mathrm{~mm} / \mathrm{min}$ were applied during the bending test.

The water absorption (WA) test was carried out based on ASTM D570 in which the fabricated kenaf composites were dried inside an oven at a temperature of $70{ }^{\circ} \mathrm{C}$ for 24 hours in order to identify the initial weight. Then, samples were immersed inside the distilled water. The weight of composites was measured every day until 30 days and the rate of water absorption was calculated using the following formula:

$$
W A=\frac{M_{1}-M_{0}}{M_{0}} \times 100
$$

where WA stands for water absorption, $\mathrm{M}_{0}$ denotes the initial mass of the specimen, and $\mathrm{M}_{1}$ represents the dried mass of the sample after removing from the distilled water. 
The tensile fracture surfaces were characterized using a scanning electron microscope (SEM) model JOEL JSM-5600. The specimens were coated with Palladium (Pd) where the coating process was performed using a Quarom SC7620 Sputter Coater at $10 \mathrm{Kv}$ voltage. Flexural failure modes were examined using an optical microscope (Nikon Measuring Microscope Trinocular Head, model MM-TRF).

\section{RESULTS AND DISCUSSION}

\subsection{Tensile Properties of Kenaf Reinforced Epoxy Matrix Composites}

Figure 2(a,b) shows the tensile properties of fabricated kenaf composites at three different fiber loadings (30 vol.\%, $40 \mathrm{vol} . \%$, and $50 \mathrm{vol} . \%$ ) and also pristine epoxy as a control sample. From the figure, the tensile strength and modulus of pristine epoxy was recorded at $45 \mathrm{MPa}$ and $1.52 \mathrm{GPa}$, respectively. The incorporation of kenaf fiber has improved the values of tensile strength and the modulus of the fabricated composite panel. Moreover, it can be noticed that, when the fiber content was increased from 30 vol.\% to 40 vol.\%, the tensile strength of the fabricated kenaf composites increased. However, when kenaf fibers were loaded up to $50 \mathrm{vol} \%$ in the composite system, the value of tensile strength was prone to be decrease. Specifically, the highest tensile strength attained was $76.67 \mathrm{MPa}$ when $40 \mathrm{vol} . \%$ fibers were loaded into the system where the performance of tensile strength decreased by $7.45 \%(70.96 \mathrm{MPa})$ when $30 \mathrm{vol} . \%$ fiber content was utilized. Surprisingly, the value of tensile strength drastically decreased by $34.08 \%(50.54$ $\mathrm{MPa}$ ) when the level of fibers increased to $50 \mathrm{vol} \%$. The same trend as tensile strength was observed in the value of the tensile modulus, which increased in the level of fiber content from $30 \mathrm{vol} . \%$ (2.09 GPa) to 40 vol.\% (2.31 GPa). This improved the behavior of tensile modulus. Whereby, the increment of fiber content up to $50 \mathrm{vol} \%$ (1.88 $\mathrm{GPa})$ resulted in a decrement in the performance of the tensile modulus.
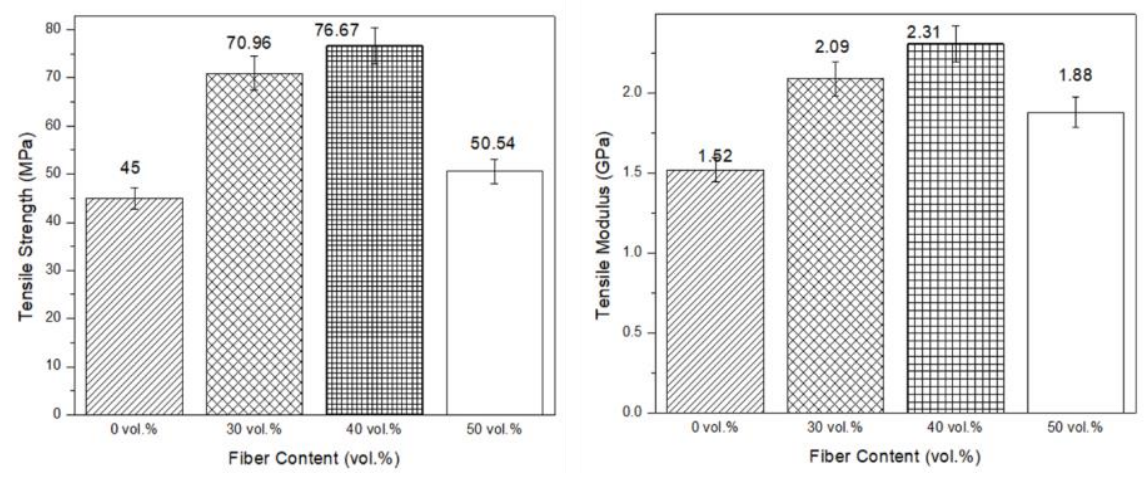

Fig. 2: (a) Tensile strength and (b) tensile modulus of fabricated kenaf composites at different fiber contents.

It is believed that the behavior of the tensile properties was influenced by the adhesion characteristic between the plies of kenaf fibers with epoxy resin. This is in agreement with Cisneros-López et al. [14] where outstanding tensile properties were probably due to the formation of a better fiber-matrix interface that resulted from excellent adhesion between fiber and matrix phases. With regards to the current work, the results indicate that the epoxy resin can provide sufficient support in binding the kenaf fibers at 40 vol.\% fiber content in which the formation of high lamination quality was achieved at this condition. With regards to the current work, the results indicate that the epoxy resin can provide sufficient support in binding the kenaf fibers at 40 vol.\% fiber content in which the 
formation of high lamination quality was achieved at this condition. It is due to its ability to form a strong fiber-matrix interface between the kenaf fibers and the epoxy resin. Therefore, 40 vol.\% kenaf composite is able to endure more tension load as compared to 30 vol. $\%$ and 30 vol.\% before experiencing permanent tensile failure. Figure 3 shows the stress-strain curve of kenaf composites at different fiber loadings. From the stress-strain curve, a steep slope can be observed in the kenaf composite that was loaded with 40 vol.\% fibers. In fact, the steep slope indicates the composite material tends to exhibit higher tensile modulus as compared to the composite that displays the low slope [15]. It is due to the ability to reach a high fracture point before experiencing external tensile failure. It seems that kenaf composites fabricated with 40 vol.\% display higher fracture points than $30 \mathrm{vol} \%$ and 50 vol.\% kenaf composites. Meanwhile, the lowest fracture point was noticed in kenaf composite that produced using 50 vol.\% of fibers. These findings have validated the results obtained in tensile properties discussed in the previous point.

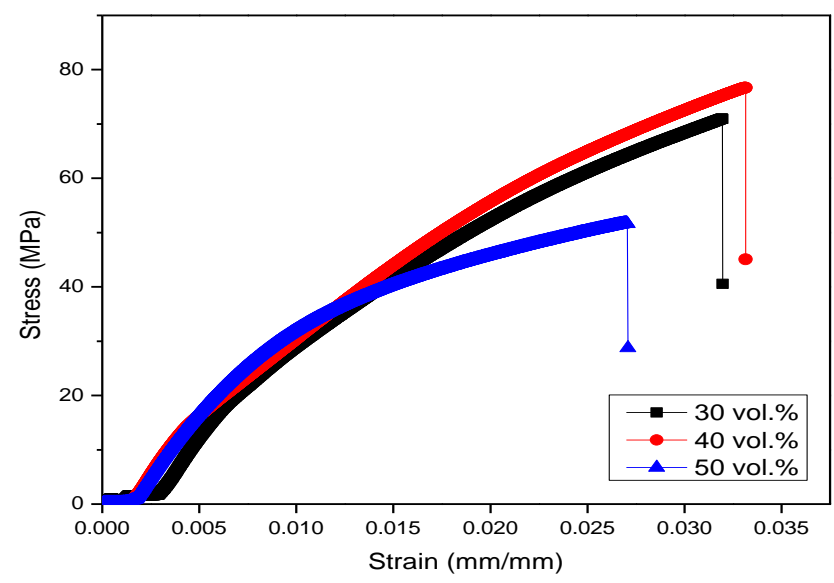

Fig. 3: The stress-strain curve of fabricated kenaf composites at different fiber loadings.

Figure 4(a-f) shows the micrographs for each of the kenaf composites. The appearance of fiber agglomeration due to poor wettability between fibers and matrix can be detected in the fabricated kenaf composites especially in kenaf composites $50 \mathrm{vol} \%$ of fiber content. Severe fiber agglomeration in the $50 \mathrm{vol} \%$ kenaf composite signifies this composite panel experienced poor adhesion between fibers and matrix constituent in which fibers can separate easily from the matrix during the application of tension loads. Based on Fig. 4(b), kenaf composite that was loaded with 40 vol.\% fibers was able to display better fiber-matrix lamination than 30 vol. $\%$ and 50 vol.\% kenaf composites. At high magnification, all fabricated kenaf composites exposed toward fiber pull-out failure as shown in Fig. 4(d-f). From Fig. 4(f), it can be noticed that the presence of the gap between matrix phase and fiber appeared in kenaf composite with 50 vol.\% fiber loading. This reveals that epoxy resin was unable to bind the fibers efficiently and therefore disturbed the process of transferring tension load from matrix to fibers. As a result, kenaf composite with 50 vol.\% was prone to show poor tensile strength and modulus. This is in agreement with the findings from the previous discussion.

\subsection{Flexural Properties of Kenaf Reinforced Epoxy Matrix Composites}

Flexural properties of fabricated pristine epoxy and kenaf composites at three different fiber loadings, namely $30 \mathrm{vol} . \%, 40 \mathrm{vol} . \%$, and 50 vol.\% are shown Fig. 5(a,b). Based on Fig. 5(a), the value of flexural strength and modulus of pristine epoxy stated at 48.52 $\mathrm{MPa}$ and 3.26 GPa, respectively. 

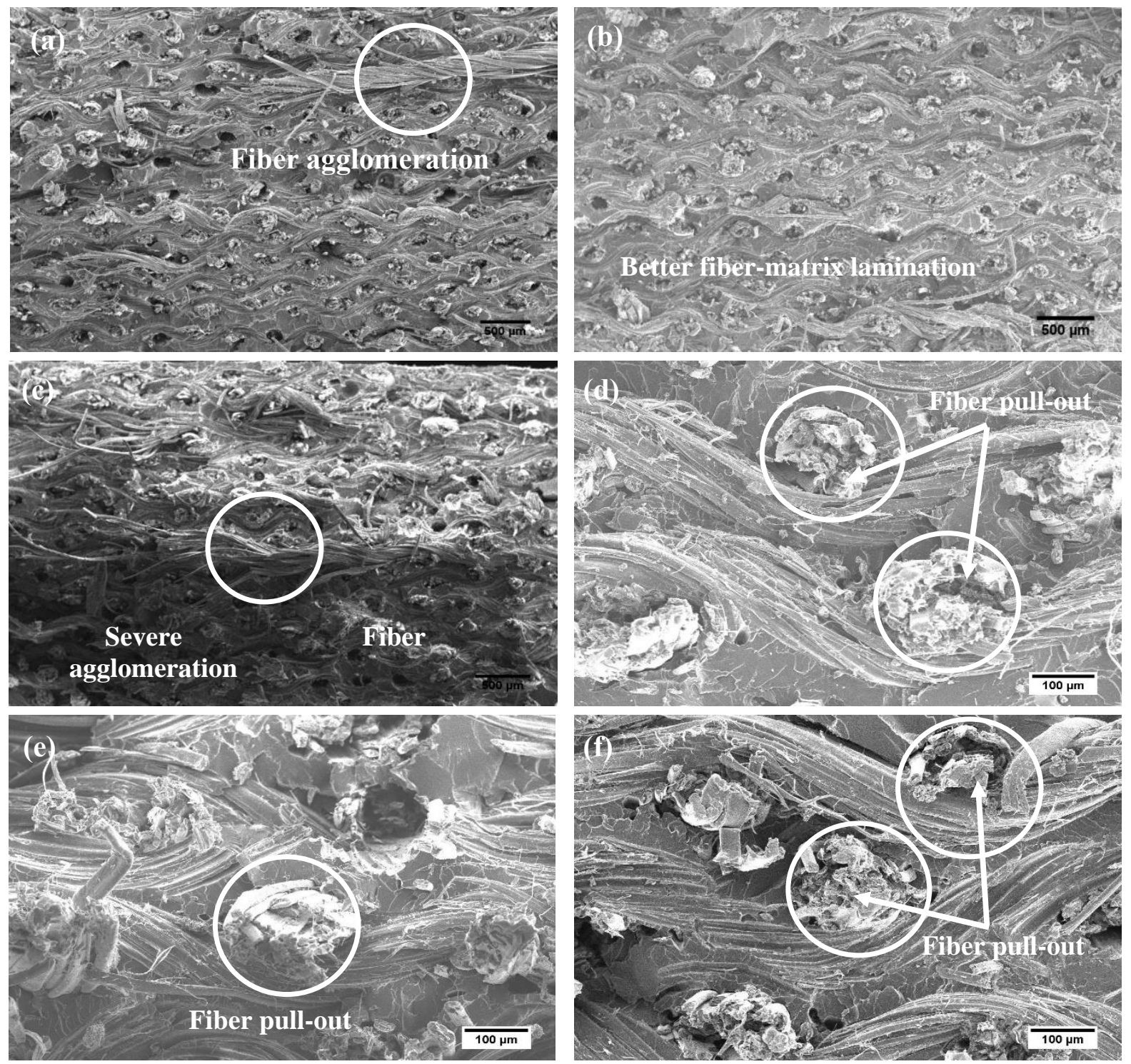

Fig. 4: Tensile fracture micrographs of fabricated kenaf composites - (a) $30 \mathrm{vol} \%$, (b) 40 vol.\%, and (c) 50 vol.\% fiber loadings at $\times 25$ magnification and (d) $30 \mathrm{vol} . \%$, (e) 40 vol. $\%$, and (f) 50 vol.\% fiber loadings at $\times 150$ magnification.

The increment in the trend of flexural strength can be spotted when kenaf fibers were introduced into the composite system. Moreover, when kenaf fiber was increased from 30 vol.\% to $40 \mathrm{vol} . \%$, the highest flexural strength can be observed at the value recorded at 61.24 MPa. It is believed that this increment is due to the adequacy of epoxy resins to laminate the fiber efficiently [16]. As a result, once the bending load touched the $40 \mathrm{vol} \%$ kenaf composites, the loads were carried by the whole system rather than the individual ply. Therefore, greater loads are needed to break the sample before suffering from flexural failure. The introduction of $50 \mathrm{vol} . \%$ kenaf fibers result in reducing the performance of the composite material where the value of flexural strength was reduced by $16.88 \%$ in comparison to $40 \mathrm{vol} . \%$ fiber content. It indicates that, the utilization of kenaf fibers up to 50 vol.\% was unable to provide optimum reinforcing effect toward the composite system. Moreover, at high level of fiber content, it is difficult for natural-based composite materials to maintain their strong fiber-matrix interface due to poor compatibility with most polymer matrices [17]. Therefore, this composite material is incapable of staying longer under bending loads, hence, resulting in poor flexural properties. A similar pattern 
of flexural strength was found in the values of flexural modulus in which the highest flexural modulus gained at 4.2 GPa belongs to kenaf composite loaded with 40 vol.\% fibers. The values of flexural modulus decreased by $10.23 \%$ and $25 \%$ with the employment of $30 \mathrm{vol} . \%$ and $50 \mathrm{vol} . \%$ fiber content, respectively.

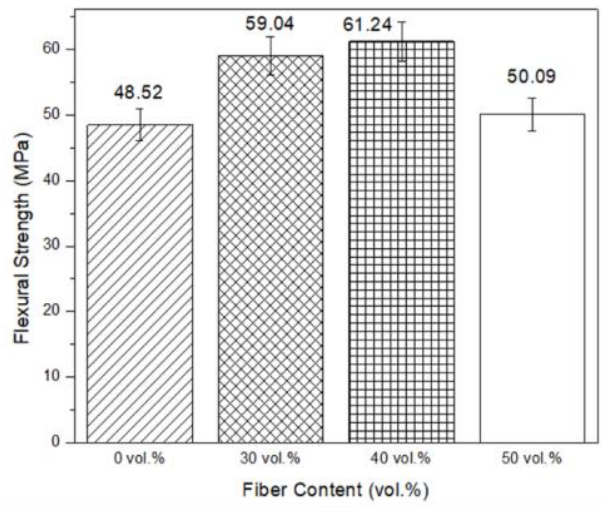

(a)

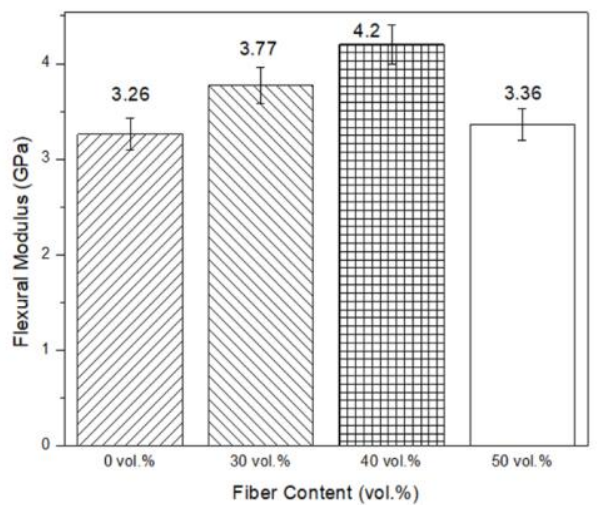

(b)

Fig. 5: (a) Flexural strength and (b) flexural modulus of kenaf composites fabricated with different fiber contents.
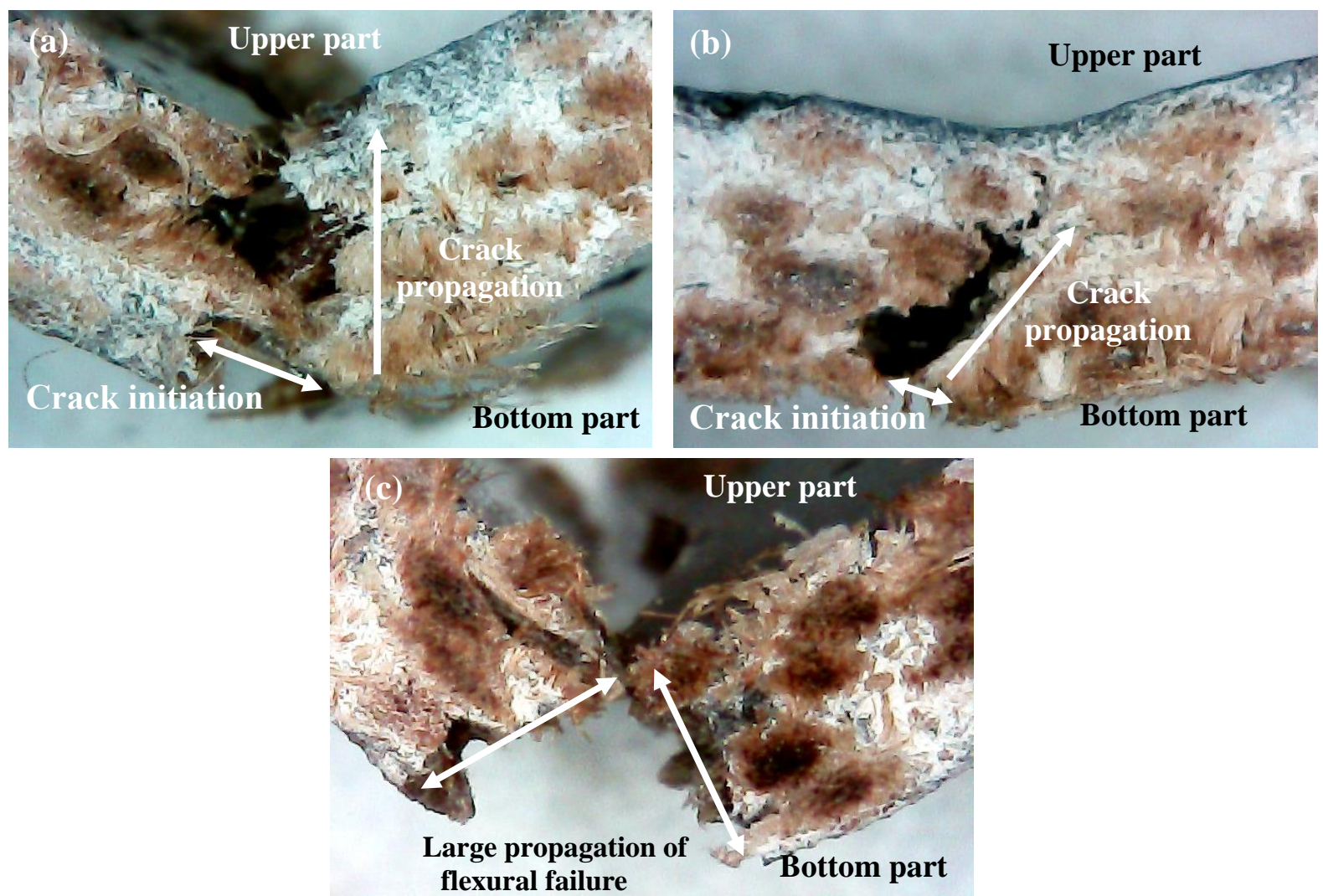

Fig. 6: Flexural failure of kenaf composites at (a) 30 vol.\%, (b) 40 vol.\%, and (c) $50 \mathrm{vol} . \%$ of fiber content.

Figure $6(\mathrm{a}-\mathrm{c})$ visualizes failure modes of kenaf composites under a flexural condition. The behavior of crack initiation and propagation can be explained based on this figure. The cracks start to initiate at the bottom part of the kenaf composites when the upper part of composite panels are unable to resist the applied bending load due to high stress 
concentration. Then, these cracks spread and propagate in the middle layer of kenaf composites until reaching the maximum fracture point and causing permanent bending failure. Based on Fig. 6(a-c), all the fabricated kenaf composites suffered from fiber breakage failure in which this failure was probably due to the presence of microcracks resulting from the incapability of composite panels to maintain their strong interfacial bonding between fiber-matrix interfaces [18]. Severe fiber breakage occurred in the kenaf composite that was fabricated using $50 \mathrm{vol} . \%$ fibers where it caused the composite panel to separate. This indicates that cracks can infiltrate easily within the layers of $50 \mathrm{vol} . \%$ kenaf composite due to poor interfacial bonding between layers of kenaf fiber and epoxy resins. Based on Fig. 6(b), less crack propagation can be noticed in the kenaf composite with 40 vol.\% fiber content contrasted over 30 vol. $\%$ and 50 vol.\% composite panels. The formation of a better fiber-matrix interface due to high wettability between kenaf fibers and epoxy resins has slowed down the propagation of cracks within the composite body. As a result, kenaf composite with 40 vol.\% compositions of fibers capable of enduring more bending loads and consequently helping this composite to exhibit better flexural properties as compared to the other kenaf composites.

\subsection{Water Absorption Behavior of Kenaf Composite Panels}

Figure 7(a) shows the rate of water absorption for kenaf composites fabricated with three different fiber loadings. The rate of water absorption was measured every day up to 30 days. At the beginning of the process, the rate of water absorption for kenaf composites in all-fiber loadings increased linearly, then the trend of water uptake started to slow down until reaching saturation after a prolonged period. This trend was in accordance with the diffusion theory known as the Fickian diffusion process [19]. Based on the graph, the highest rate of water absorption was displayed by kenaf composite fabricated using 50 vol.\% fibers (43.33\%), followed by kenaf composite with 40 vol.\% fiber content (30.46 $\%$ ). Whereby, the lowest rate of water absorption recorded at $25.49 \%$ belongs to kenaf composite that loaded with 30 vol.\% fibers. These values indicate that increases in the amount of kenaf fibers in the composite system tend to increase the rate of water absorption of fabricated composite panels.
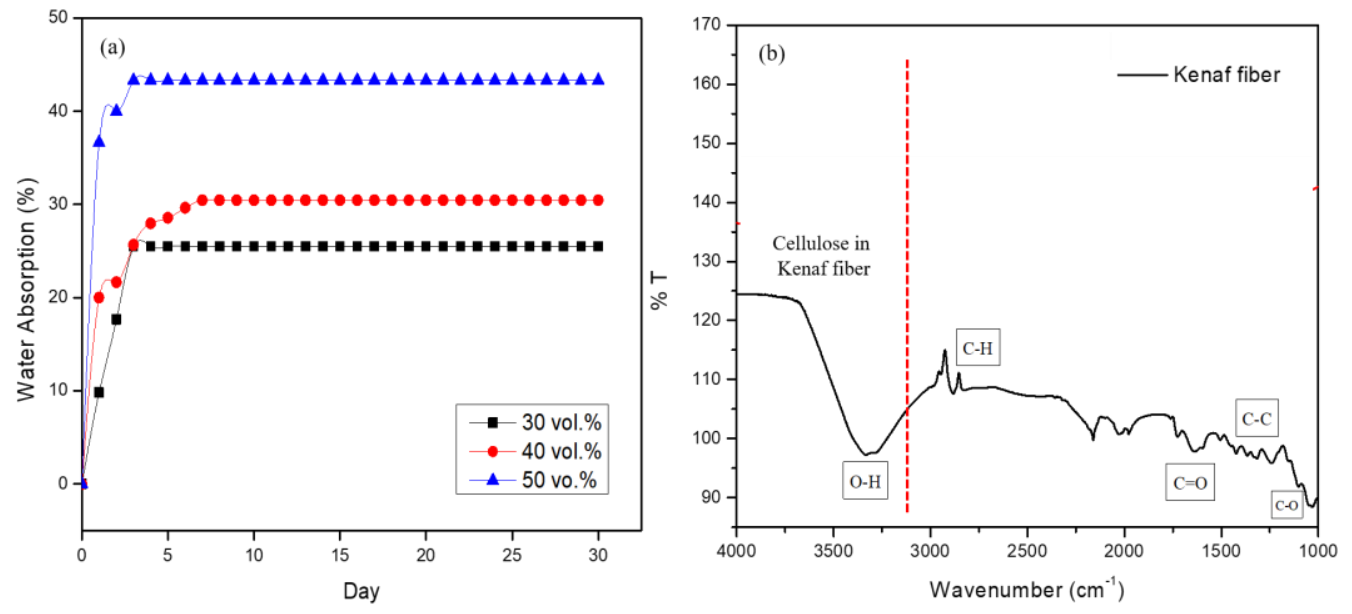

Fig. 7: The rate of water absorption of kenaf composites at 30 vol. $\%, 40$ vol. $\%$, and 50 vol.\% fiber content for 30 days.

This phenomenon occurred due to the nature of natural fibers in which they are very responsive to the watery environment [20]. The presence of cellulose components in kenaf fibers denotes hydroxyl groups that are the principal contributors to moisture absorption 
and increase the attractiveness to the watery condition [21]. The presence of $\mathrm{OH}$ groups from cellulose has been confirmed by FTIR spectra as shown in Fig. 7(b). Thus, increasing the level of kenaf fibers will increase the tendency of the composite panel to absorb more water as compared to the composite with fewer kenaf fibers composition. Moreover, it also believed that high water absorption, especially in kenaf composite with 50 vol.\% fiber contents, is probably due to the ineffectiveness of epoxy resins to play their role as a barrier in protecting the composite from the watery environmental attack. Therefore, it may contribute to the fiber swelling phenomena in which this event can promote the appearance of microcracks [21]. Thus, the process of water uptakes becomes dominant and active in the microcrack region. As a result, kenaf composite panels with higher fiber content (50 vol.\%) are prone to absorb more water in comparison to kenaf composites that are loaded with low fiber content (30 vol.\% and 40 vol. $\%$ ).

\section{CONCLUSION}

The behaviors of kenaf composites in terms of mechanical properties, water absorption, and failure analyses have been studied where the effects of fiber contents toward these properties were carefully evaluated. Thus, it can be concluded that:

a) The incorporation of kenaf fibers from 30 vol.\% to 40 vol. $\%$ successfully improved the mechanical properties (tensile and flexural properties) of fabricated composite panels as compared to the pristine epoxy. Whereas the utilization of kenaf fibers up to $50 \mathrm{vol} . \%$ has reduced the performances of tensile and flexural properties of kenaf composites.

b) Common tensile failure, which is fiber pull-out able to be detected in all fabricated kenaf composites, and fiber breakage failures appeared in the flexural failure. These failures were severely found in the kenaf composite that was fabricated using 50 vol.\% fiber content.

c) Increasing in the level of kenaf fibers is prone to increase the rate of water absorption of fabricated kenaf composite panels.

\section{ACKNOWLEDGEMENT}

The authors would like to express their gratitude to the Ministry of Higher Education (MOHE) of Malaysia for the support through the awarded grant (FRGS 17-033-0599), Kulliyyah of Engineering, International Islamic University Malaysia (IIUM), and also to the IIUM Research Management Centre for facilitating this project.

\section{REFERENCES}

[1] Saadati Y, Lebrun G, Chatelain JF and Beauchamp Y (2020) Experimental investigation of failure mechanisms and evaluation of physical/mechanical properties of unidirectional flaxepoxy composites. J. Composite Materials, 54(20): 1-21. doi:10.1177/0021998320902243

[2] Dhaliwal GS, Dueck SM, Newaz GM. (2019) Experimental and numerical characterization of mechanical properties of hemp fiber reinforced composites using multiscale analysis approach. SN Appl. Sci., 1: 1361. https://doi.org/10.1007/s42452-019-1383-6

[3] Madhu P, Sanjay MR, Senthamaraikannan P, Pradeep S, Saravanakumar SS and Yogesha B (2018) A review on synthesis and characterization of commercially available natural fibers: Part II. Journal of Natural Fibers, 16: 25-36. doi:10.1080/15440478.2018.1453433 
[4] Thyavihalli Girijappa YG, Mavinkere Rangappa S, Parameswaranpillai J and Siengchin S (2019) Natural fibers as sustainable and renewable resource for development of eco-friendly composites: a comprehensive review. Frontiers in Materials, 6: 1-14. doi:10.3389/fmats.2019.00226

[5] Mochane MJ, Mokhena TC, Mokhothu TH, Mtibe A, Sadiku ER, Ray SS, Ibrahim ID, Daramola OO (2019) Recent progress on natural fiber hybrid composites for advanced applications: A review. Express Polymer Letters, 13(2): 159-198. doi:10.3144/expresspolymlett.2019.15

[6] Siakeng R, Jawaid M, Ariffin H, Sapuan SM, Asim M and Saba N (2018) Natural fiber reinforced polylactic acid composites: A review. Polymer Composites, 40: 446-463. doi: $10.1002 /$ pc. 24747

[7] Navaneethakrishnan G, Karthikeyan, T, Saravanan S, Selvam V, Parkunam N, Sathishkumar G and Jayakrishnan S (2019) Structural analysis of natural fiber reinforced polymer matrix composite. Materials Today: Proceedings, 21: 7-9. doi:10.1016/j.matpr.2019.05.295

[8] Kumar R, Ul Haq MI, Raina A and Anand A (2018) Industrial applications of natural fibrereinforced polymer composites - challenges and opportunities. International Journal of Sustainable Engineering, 12: 212-220. doi:10.1080/19397038.2018.1538267

[9] Javadian A, Smith Ian FC, Nazanin F and Hebel DE (2019) Mechanical properties of bamboo through measurement of culm physical properties for composite fabrication of structural concrete reinforcement. Frontiers in Materials, 6: 1-15.

[10] Gupta MK. (2018) Effect of variation in frequencies on dynamic mechanical properties of jute fibre reinforced epoxy composites. Journal of Materials and Environmental Sciences, 9: 100-106. https://doi.org/10.26872/jmes.2018.9.1.12

[11] Yang MFM, Hamid H, Abdullah AM. (2018) Potential use of cellulose fibre composites in marine environment - A Review. in: Öchsner A. (eds) Engineering Applications for New Materials and Technologies. Advanced Structured Materials, Springer, Cham, 86: 22-55.

[12] Kaiser K, Schmid M, Schlummer M. (2017) Recycling of polymer-based multilayer packaging: A review. Recycling, 3: 1-26. doi:10.3390/recycling3010001

[13] Yuhazri MY, Amirhafizan MH, Abdullah A, Husin MA, Kamarul AM and Lau STW (2018) Kenaf fibre composites as promising green-composites for automotive car door map pocket application. International Journal of Mechanical \& Mechatronics Engineering, 8: 15-21.

[14] Cisneros-López EO, González-López ME, Pérez-Fonseca AA, González-Núñez R, Rodrigue D and Robledo-Ortíz JR (2016) Effect of fiber content and surface treatment on the mechanical properties of natural fiber composites produced by rotomolding. Composite Interfaces, 24: 35-53. doi:10.1080/09276440.2016.1184556

[15] Alberto M. (2013) Introduction of fibre-reinforced polymers - Polymers and Composites: Concepts, Properties and Processes. Fiber Reinforced Polymers - The Technology Applied for Concrete Repair IntechOpen, pp. 3-40.

[16] Harsha AP and Arjula S. (2010) Influence of fibre orientation on three-body abrasive wear behaviour of unidirectional carbon fibre-reinforced polyetherimide composite. Journal of Materials Science, 46: 983-991. doi:10.1007/s10853-010-4856-y

[17] Adekomaya O, Jamiru T, Sadiku R and Huan Z (2017) Negative impact from the application of natural fibers. Journal of Cleaner Production, 143: 843-846. doi:10.1016/j.jclepro.2016.12.037

[18] Wang W, Chouw N, Jayaraman K. (2016) Effect of thickness on the impact resistance of flax fibre-reinforced polymer. J. Reinforced Plastics and Composites, 35: 1277-1289. doi: $10.1177 / 0731684416648780$

[19] Peret T, Clement A, Freour S, Jacquemin F. (2019) Homogenization of Fickian and nonFickian water diffusion in composites reinforced by hydrophobic long fibers: Application to the determination of transverse diffusivity. Composite Structures, 226: 1-9. doi:10.1016/j.compstruct.2019.111191 
[20] Rozali NA, Abu Bakar MB, Masri MN, Sulaiman MA, Mohamed M, Ahmad Thirmizir MZ (2017) Mechanical and water absorption properties of hybrid kenaf/glass fibre mat reinforced unsaturated polyester composites. Materials Science Forum, 888: 228-233. doi:10.4028/www.scientific.net/msf.888.228

[21] Maslinda AB, Abdul Majid MS, Ridzuan MJM, and Syayuthi ARA (2017). Water absorption behaviour of hybrid interwoven cellulosic fibre composites. IOP Conf. Series: Journal of Physics: Conf. Series, 908: 012015. doi:10.1088/1742-6596/908/1/012015 